$\begin{array}{ll}\text { Variants } & \begin{array}{l}\text { Variants } \\ \text { The Journal of the European Society for Textual } \\ \text { Scholarship }\end{array}\end{array}$

$12-13$ | 2016

Varia

\title{
Stratigraphic Soundings: A Genetic Approach to the German Poet Thomas Kling
}

\section{Gabriele Wix}

\section{OpenEdition}

\section{Journals}

Electronic version

URL: http://journals.openedition.org/variants/334

DOI: 10.4000/variants.334

ISSN: 1879-6095

\section{Publisher}

European Society for Textual Scholarship

\section{Printed version}

Date of publication: 31 December 2016

Number of pages: 125-147

ISSN: 1573-3084

\section{Electronic reference}

Gabriele Wix, «Stratigraphic Soundings: A Genetic Approach to the German Poet Thomas Kling », Variants [Online], 12-13 | 2016, Online since 01 May 2017, connection on 10 December 2020. URL http://journals.openedition.org/variants/334 ; DOI : https://doi.org/10.4000/variants.334 


\section{Stratigraphic Soundings}

\section{A Genetic Approach to the German Poet Thomas Kling}

Gabriele Wix

Abstract: Using the genesis of the Manhattan poems by the German poet Thomas Kling (1957-2005) as a case study, this article uses the metaphor "stratigraphic soundings" as a means to characterize a writing process which is not based on variants or "réécriture", but on language installations. Findings in Kling's archive testify to the poet's role as an archaeologist of language; they also shape the role of the editor who likewise undertakes test drillings into a poetry of "supersedimented textuality" and "bottomless stratigraphy" (Jacques Derrida). Keywords: Language installation, variants, writing process, self-archiving, poststructuralism, German poetry.

THINGS THEMSELVES

ON TOP OF OTHER THINGS

ON TOP OF SOMETHING ELSE

NOW \& THEN

- Lawrence Weiner

\section{The author and his archive}

Aт тне тіме of his death in 2005, aged 47, Thomas Kling was already said to be "more influential and formative in terms of style than almost any other poet of his generation" (Gumz 2005). ${ }^{1}$ Indeed, Kling's engagement in the German literary poetry world had no equal at that time.

The poetry which he published from 1977 to 2005 make up the core of his work. But he was also a performer of his own poetry, an essayist, a translator, and on top of that the editor of an outstanding anthology of poetry in the German language consisting of 200 poems from the Middle Ages to the present which he simply called

1 I would like to thank Ute Langanky and Ricarda Dick (Thomas Kling Archiv, Stiftung Insel Hombroich) for permission to reproduce documents from the archive as well as for their kind support in answering my inquiries. 
Sprachspeicher (Language Storage) (see Kling 2001b). ${ }^{2}$ The title may be considered programmatic for his own poetry: as much as Kling pointed to his interest in history and contemporary culture, what he was deeply concerned with was the multi-layered nature of language which preserves memory, whether spoken or written, whether contemporary or from the past, whether dialect, poetic language, professional jargon or slang. Kling was the intertextual writer per se or, as he put it himself, a "Spracharchäologe" (Kling 1996, blurb) (language archaeologist) (see also Kling 2001a, 206).

Kling's archive and personal library survive complete intact in the place where he lived and worked during the last ten years of his life, the Raketenstation Hombroich on the Lower Rhine, a former missile base and silent witness of the Cold War. The Thomas Kling Archiv is now part of the Stiftung Insel Hombroich to which it was left by his wife, the artist Ute Langanky. Most of the documents in the archive were catalogued by the Heinrich-Heine-Institut in Düsseldorf between November 2008 and June 2011 (see Scharfschwert 2012, 383). In preparation for an exhibition on Thomas Kling, Kerstin Stüssel and I were the first to explore the archive with a view to publishing a facsimile edition with diplomatic transcription showing the genesis of Kling's iconic Manhattan poems (see Kling 2013).

The poems are entitled "Manhattan Mundraum" ("Manhattan Mouthspace") and "Manhattan Mundraum Zwei" ("Manhattan Mouthspace Two"). ${ }^{3}$ Both poems open two of his poetry books: the first is morsch (rotten) (Kling 1996), which is the first volume Kling published after he had moved from Cologne to the Lower Rhine; the second is Sondagen (Test Trenches / Stratigraphic Soundings) (Kling 2002), and not only due to this prominent position can it be assumed that they play a pivotal role in his poetry.

2 There are only very few English translations of Kling's poems and statements. Unless specified differently, all suggestions for possible translation are my own, adhering as closely as possible to the source text.

As far as I know "Manhattan Mundraum" has not been translated yet. The translation of the title refers to "Manhattan Mouthspace Two", Michael Hofmann's translation of “Manhattan Mundraum Zwei” (see Kling 2004b). 


\section{"supersedimented textuality" and "bottomless stratigraphy": Preliminary poetological considerations}

Kling's concept of a multilayered language, and accordingly, a multilayered writing becomes obvious in the material traces of the writing process of the first poem. It is worked out in four different documents: a notebook containing 36 pages that the author took with him to New York City in 1995 and used there from 13 to 23 November; a writing pad of nine sheets, dating from 23 February to 4 March 1966; a single sheet with a watermark; and a note from a waiter's notepad; the last mentioned documents are not dated. ${ }^{4}$ What makes the subject matter particularly attractive from the editorial point of view is the fact that all manuscripts are joined manuscripts; they consist of many layers of drafts and notes for many different poems.

There is an interesting parallel to a group of Georg Trakl's manuscripts from the collection of his sister Maria Geipel, which consists of folded sheets with many drafts for different poems. Both historical-critical editions of Georg Trakl's work separate the single drafts for each poem in question to present the material in a correct archival order (see Georg Trakl 1969 and 1995-2014). At least, the new edition publishes facsimiles of the double sheets, but it goes only half way because it does not pay attention to the consequences of this writing process for the presentation of the genesis of Trakl's poems (see Wix 2015). As to Kling, separating the different drafts from the writing pad or the notebook equally means destroying the characteristics of the author's writing process. That is why the whole notebook and the whole writing pad are presented in a material-based edition that document Kling's actual manner of working (see Kling 2013, 6-41). ${ }^{5}$

4 The notebook has not been catalogued yet. The other documents were given the archive number HHI.2008.D.KLING.2964 (Thomas Kling Archiv, Stiftung Insel Hombroich).

5 Interestingly enough, a new edition of Kurt Schwitters' writings also applies a media- and material-based way of editing in contrast to an earlier edition which was work- and author-centred (compare Schwitters 1998 and 2014). 
Looking at the archival documents in toto and considering the current academic discourse on the question of what constitutes a variation and on the notion of variant in relation to réécriture or rewriting, I would like to start with the end result: As far as the autographs are concerned, there are almost no variants, no stages of revisions as we are used to in studying the genesis of literature, but what we do encounter are inserts of test trenches from the sedimentation of language, which generates a text of multiple writings. With regard to the methods of critique génétique, Louis Hay uses the term "quasi-archäologische Verfahren" (Hay 1984, 307) ("quasiarchaeological methods"). Reconstructing the genesis of Kling's poems, I would argue that the concept of stratigraphy in modern archaeology might serve as a metaphor for characterizing both Kling's writing process and the genetic approach. ${ }^{6}$

Strictly speaking, stratigraphic metaphors are not new to describe language and writing. In particular, Derrida's essay on Bernard Tschumi's deconstructive conception of Parc de la Villette in Paris must be mentioned, in which Derrida is playing upon the words folie, feuille and folio, and thereby talking about writing when talking about architecture.

La masse de pierre inamovible, la verticale station de verre ou de métal que nous tenions pour la chose même de l'architecture ('die Sache selbst' ou 'the real thing'), son effectivité indéplaçable, nous l'appréhendons maintenant dans le texte volumineux d'écritures multiples : surimpression d'un Wunderblock [...], trame du palimpseste, textualité sursédimentée, stratigraphie sans fond, mobile, légère et abyssale, feuilletée, foliiforme. (Derrida 1986, 12)

[The immovable mass of stone, the vertical glass or metal plane that we had taken to be the very object of architecture (die Sache selbst or the real thing), its indisplaceable effectivity, is apprehended maintenant in the voluminous text of multiple writings: superimposition of a Wunderblock [...], palimpsest grid, supersedimented textuality, bottomless stratigraphy that is mobile, light and abyssal, foliated, foliiform.] (Derrida 1986, 13)

6 See Harris 1997, 7 and ff. Edward Harris was the first to point out clearly the special needs of an archaeological stratigraphy in contrast to a geological one and thus created the new discipline (the first edition was published in 1979). 
Not surprisingly, the archaeological term "Sondage" ("test trench" or "stratigraphic soundings") works as the title of the poetry volume by Thomas Kling from 2002: Sondagen, where he published the second poem about Manhattan. And it is again the poet himself who uses geological metaphors writing about "textus" and "granit" ("granite"), see the beginning of the first and the last stanza of his poem "Manhattan Mundraum" ("Manhattan Mouthspace") to which we shall turn our attention now:

die stadt ist der mund raum. die zunge, textus; stadtzunge der granit: geschmolzener und wieder aufgeschmolzner text. [...] (Kling 1996, 7)

[the city is the mouth space. the tongue [lingua], textus; city tongue the granite: melted and remelted text. [...]]

die stadt ist der mundraum. die zunge, textus. die namen, blicknamenzerfall. geschmolzene, bewegte, schwarzglühende suppe. steinbrei, der dickt. [...] (Kling 1996, 12)

[the city is the mouth space. the tongue [lingua], textus. the names, decay of glance of names. melted, moved, blackglowing soup. mash of stones, thickening. [...] ]

These melting and remelting processes have been shaping the space of the city as well as the language that makes up the "mouth space" of Manhattan. But at the same time it is our mouth space of which the author makes us aware by the use of language in his poem: Violating the spelling rules, the word "aufgeschmolzener" ("remelted") is separated by the line break into: "aufgeschmo- | lzner text" 
("reme- | lted text"). The reader's attention is thus drawn to the physical reading process, which especially in German is extremely difficult because of the sequence of three consonants - conforming with oral speech, the vowel " $\mathrm{e}$ " is cancelled by Kling. Feeling the tongue moving in his mouth, the reader cannot but become aware of his own mouth space. The physical space of the city, the mouth space of all the languages used in Manhattan and the reader's mouth space are melted down and reflect the author's notion of a multilayered text. Thus, the thesis on the relationship between, on the one hand, Kling's writing process and its reconstruction in the genetic approach and the concept of stratigraphy, on the other hand, should be based first of all on poetological reflections, which are very important for genetic criticism and textual scholarship, and crucial also for understanding Kling's notion of authorship. Before analysing the material traces of the writing process, it is therefore useful to take a closer look at Kling's poetics in relation to the genesis of the Manhattan poems.

The first poem on Manhattan refers to Kling's stay in New York City from 13 to 23 November 1995, following an invitation by the Goethe House to participate at the Nuyorican Poetry Festival. Initially, the poem seems to be about the author's impressions of the city he visited for the first and only time in his life. However, the title of the poem arouses suspicion. Because of the inversion of apposition and name, the title "Manhattan Mundraum" does not comply with standard usage in the German language, but it does well in English. In fact, the title evokes the American novel Manhattan Transfer, an assumption verified in the notebook: "titel: DOS PASSOS-Variante" ("title: variant of DOS PASSOS") (Kling 1995, 30; see also Kling 2013, 16). First of all, this note by the author shows the need to take into account that there are intertextual layers originating from foreign languages: "In principle, we have to assume that any textual element has intertextual relatives and very often they speak foreign languages" (Dedner 2012, 130). Secondly, it demonstrates that the notebook should not only be considered a draft for the poems, but also a commentary on them. The objective of John Dos Passos' 1925 novel to which Kling is referring in the title of the Manhattan poems is similar to the one Kling is pursuing in his poetological program: melting language and techniques from the most different contexts and media, as for example from 
literature, film, newspaper, and oral speech. Hence the title of the poem applies not only to New York City, but also to poetry itself in a self-referential discourse.

Hardly coincidentally, the postmodern architect Bernard Tschumi - the subject of Derrida's essay cited above - also refers to Dos Passos' novel in his exhibitions entitled The Manhattan Transcripts and his book of the same title. Tschumi's introduction to his book could equally apply to Kling's poetry, see his descriptions of his own way of isolating "frozen bits of action" (Tschumi 1994, 10), developing spaces "from shot to shot" (Tschumi 1994, 11), and his emphatic insistence on referring to reality:

The Transcripts always presuppose a reality already in existence, a reality waiting to be deconstructed - and eventually transformed. They isolate, frame, 'take' elements from the city. Yet the role of the Transcripts is never to represent; they are not mimetic. (Tschumi 1994, 8)

As to both of Kling's Manhattan poems, this reality "already in existence" is on the one hand the author's first visit to Manhattan and all the references to the historical traces. On the other hand, it consists of the reports on the planes crashing into the Twin Towers in 2001, especially the medial representation in TV as infinite loops, combined with the author's eye and ear witness of Manhattan in 1995. Equally in line with Tschumi, Kling points out that the role of poetry is never to represent, that poetry is not mimetic. The key word in his poetics is "translating the realities", whereby for him "realities" comprise also the use of language both past and present:

Wir haben es mit der Schwierigkeit des Übersetzens zu tun, des Übersetzens von Wirklichkeiten, von Realien; von geschichtlichen, kultur- und zeitgeschichtlichen Realien. Wir haben es mit den Realien der gesprochenen und der toten Sprachen zu tun. Das Durchtauchen all der vorhandenen, seienden Sprachräume. (Kling 1993, 11)

[We are dealing with the difficulty of translating, translating the realities, the real-life facts of historical, cultural and contemporary realities. We are dealing with the realities, the real-life facts of spoken and dead languages. Diving through all existing languages.] 


\section{"Manhattan Mouthspace": Material traces of the writing process}

To substantiate the thesis that the reconstruction of the writing process of "Manhattan Mouthspace" can be characterized as stratigraphic soundings and that the writing process itself is based on the installation of test trenches, I will concentrate on just one stanza: the $11^{\text {th }}$ and second to last stanza from the first poem which is mainly about Penn Station on $34^{\text {th }}$ Street and the dilapidated state of the subway stations, rust flaking from the iron pipes, water running down the walls. A translation of this stanza is extremely difficult because of Kling's playing upon the etymology of words. The word "-blattern" refers to "Blattern", the name of the disease "small pox", but there is an etymological affinity with "Blatt", which in German means "leaf" as well as "sheet". Furthermore, "-blattern" refers to "blättern", which means "to browse". Consequently, we can say that alone with the use of a single word like "-blattern", Kling unveils multiple layers of language, an etymological, "archaeological" process that in this case cannot be very adequately translated into English.

gingkos. geriffelter slang, der die bödn bedeckt. eins tiefer (dautendey: "der bühnenraum ist ein gehirn") trieft wasser, unablässig aus den rostschrundn, $34^{\text {th }}$, pennsylvania station, von vonne subwaywände; rostplackn, -blattern, vermorschtes rohrsystem; ein drippeln, schneller, aus di deckn. die zunge gkürzt, ein tag unter tags, unter vielen (Kling, 1996, 12)

[gingkos. checkered slang, covering the floors. one below (dautenday: "the stage is a brain") there is water dripping, ceaselessly out of the cracks of rust, $34^{\text {th }}$, pennsylvania station, off of the subway walls; lumps of rust, flakes of rust, rotten system of pipes; a trickling, faster, from the ceilings. the tongue shortened, a day underground, among many others] 
Looking at the drafts it becomes obvious that the stanza is formed on the basis of test trenches, which are taken from wide-ranging contexts. All the expressions that Kling transferred from the handwritten notes (see Figures 1-5) into his poem are marked up in bold type so that the reader can follow the genesis, but only with the reservation that the exact chronology of the writing process itself cannot be reconstructed. There are too many missing links that we possibly might find by a forensic analysis of the digital material. On the basis of the autographs, we can only reconstruct the "installation" of the sources from their contexts. ${ }^{7}$ Anyway, it is exciting enough to see in the course of the "installation" that there are only very few words that could not be traced in the documents at hand. ${ }^{8}$

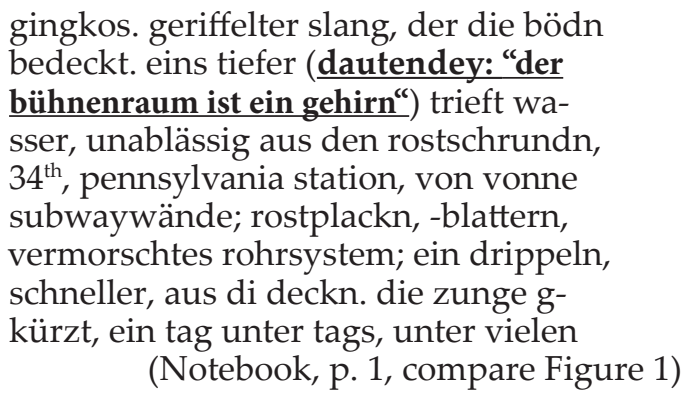

7 The author himself calls his poems "Sprachinstallationen" ("language installations") (see Kling 2006). This term leads to a very particular aspect of Kling's poetry. Peer Trilcke shows that the length of Kling's lines often corresponds to a fixed amount of signs and blanks, which he characterizes as "grafikpoetische Praxis" or "Schriftbildnerei" (Trilcke 2012, 295) ("graphicpoetic practice" or "shaping by printing"). I would rather suggest the term sculptural or architectural writing practice. In "Manhattan Mouthspace", many stanzas are written in the form of a rectangle, alluding to the form of a skyscraper or a column. Other verses have the form of a tetrahedron. The genesis of such an architectural writing process can only be proved by a forensic analysis of Kling's hard drives because it depends on a writing process using typefaces, be it a typewriter in earlier times or a computer nowadays. Giving an outline of genetic criticism and textual scholarship in the digital age on the basis of the first genetic approach to Kling's poetry, it can be noted that genetic criticism of contemporary literature has moved, not to say been catapulted, away from traditional philological tools and methods to the needs of a digital analysis demanding software which is not yet at the disposal for general use.

8 For facsimiles and transcriptions, see Kling 2013, pp. 6-41. 

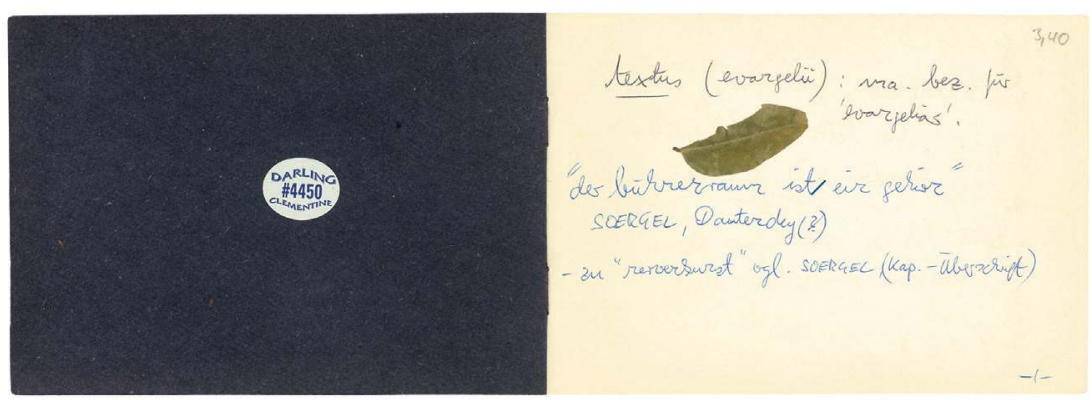

Figure 1: Thomas Kling, AUGN ZEUGN. NYC. Manhattan. Notebook, p. 1. Thomas Kling Archiv, Stiftung Insel Hombroich (uncatalogued).
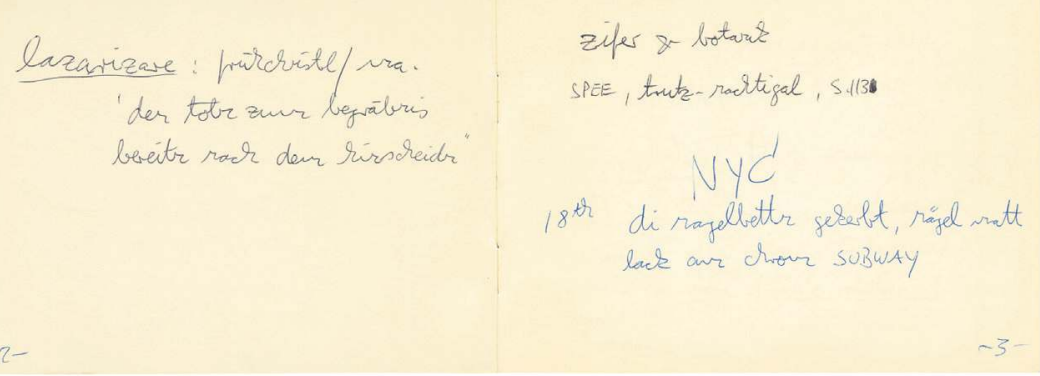

Figure 2: Thomas Kling, AUGN ZEUGN. NYC. Manhattan. Notebook, pp. 2 and 3. Thomas Kling Archiv, Stiftung Insel Hombroich (uncatalogued).

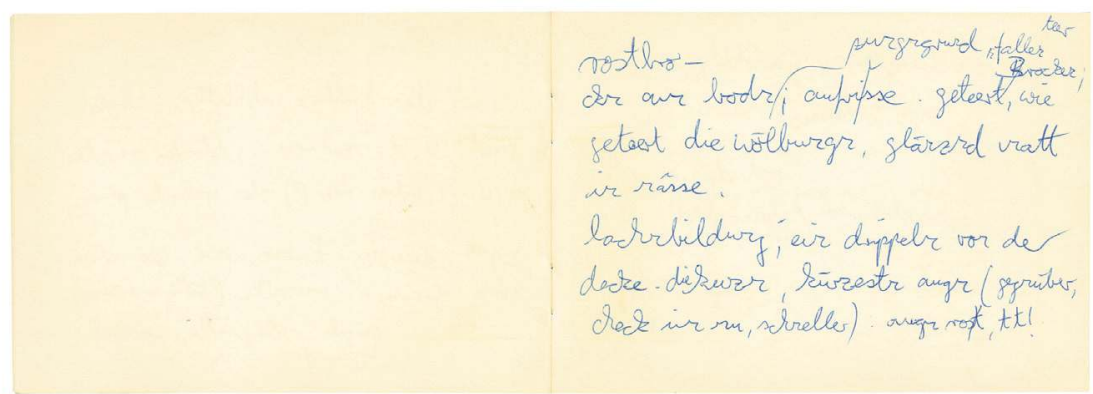

Figure 3: Thomas Kling, AUGN ZEUGN. NYC. Manhattan. Notebook, pp. 8 and 9. Thomas Kling Archiv, Stiftung Insel Hombroich (uncatalogued). 
gingkos. geriffelter slang, der die bödn bedeckt. eins tiefer (dautendey: "der bühnenraum ist ein gehirn") trieft wasser, unablässig aus den rostschrundn, $34^{\text {th }}$, pennsylvania station, von vonne subwaywände; rostplackn, -blattern, vermorschtes rohrsystem; ein drippeln, schneller, aus di deckn. die zunge gkürzt, ein tag unter tags, unter vielen

(Notebook, p. 3, compare Figure 2)

gingkos. geriffelter slang, der die bödn bedeckt. eins tiefer (dautendey: "der bühnenraum ist ein gehirn") trieft wasser, unablässig aus den rostschrundn, $3^{\text {th }}$, pennsylvania station, von vonne subwaywände; rostplackn, -blattern, vermorschtes rohrsystem; ein drippeln, schneller, aus di deckn. die zunge gkürzt, ein tag unter tags, unter vielen

(Notebook, p. 7, compare Kling 2013, 8)

gingkos. geriffelter slang, der die bödn bedeckt. eins tiefer (dautendey: “der bühnenraum ist ein gehirn") trieft wasser, unablässig aus den rostschrundn, $34^{\text {th }}$, pennsylvania station, von vonne subwaywände; rostplackn, -blattern, vermorschtes rohrsystem; ein drippeln, schneller, aus di deckn. die zunge gkürzt, ein tag unter tags, unter vielen (Notebook, p. 9, compare Figure 3)

gingkos. geriffelter slang, der die bödn bedeckt. eins tiefer (dautendey: "der bühnenraum ist ein gehirn") trieft wasser, unablässig aus den rostschrundn, $34^{\text {th }}$, pennsylvania station, von vonne subwaywände; rostplackn, -blattern, vermorschtes rohrsystem; ein drippeln, schneller, aus di deckn. die zunge gkürzt, ein tag unter tags, unter vielen (Notebook, p. 25, compare Figure 5) 


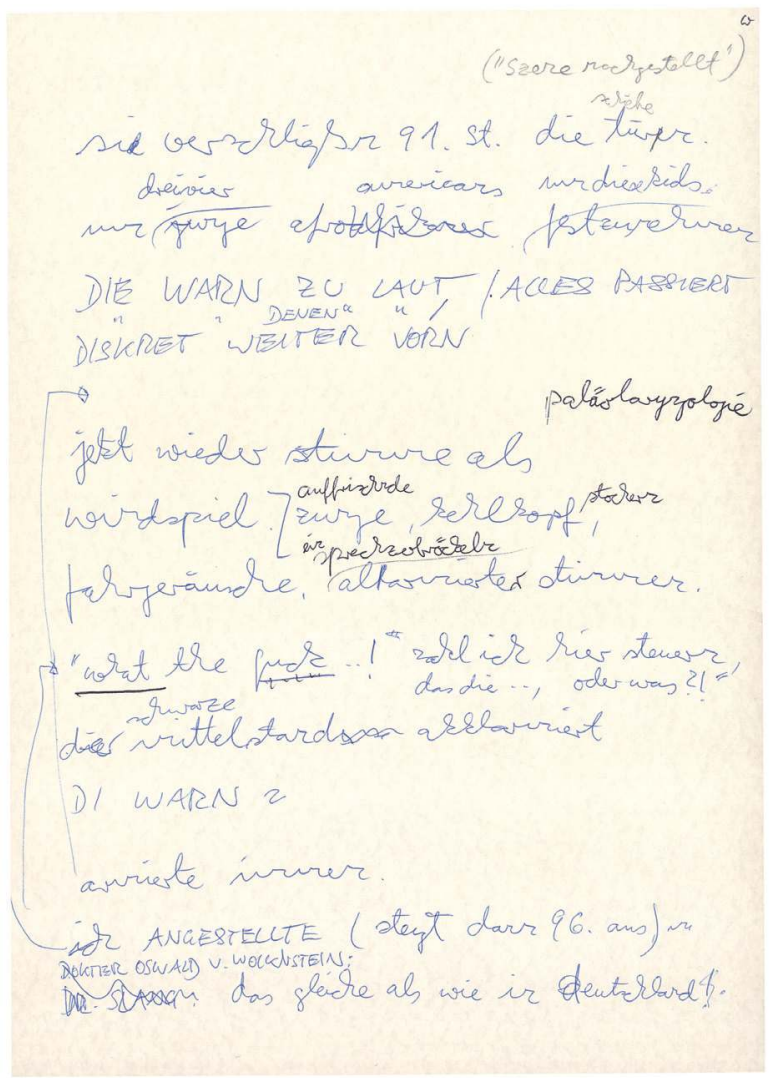

Figure 4: Thomas Kling. Writing pad, p. 9. Thomas Kling Archiv, Stiftung Insel Hombroich (HHI.2008.D.KLING.2964).

gingkos. geriffelter slang, der die bödn bedeckt. eins tiefer (dautendey: "der bühnenraum ist ein gehirn") trieft wasser, unablässig aus den rostschrundn, $34^{\text {th }}$, pennsylvania station, von vonne subwaywände; rostplackn, -blattern, vermorschtes rohrsystem; ein drippeln, schneller, aus di deckn. die zunge gkürzt, ein tag unter tags, unter vielen (Writing pad, p. 9, compare Figure 4) 


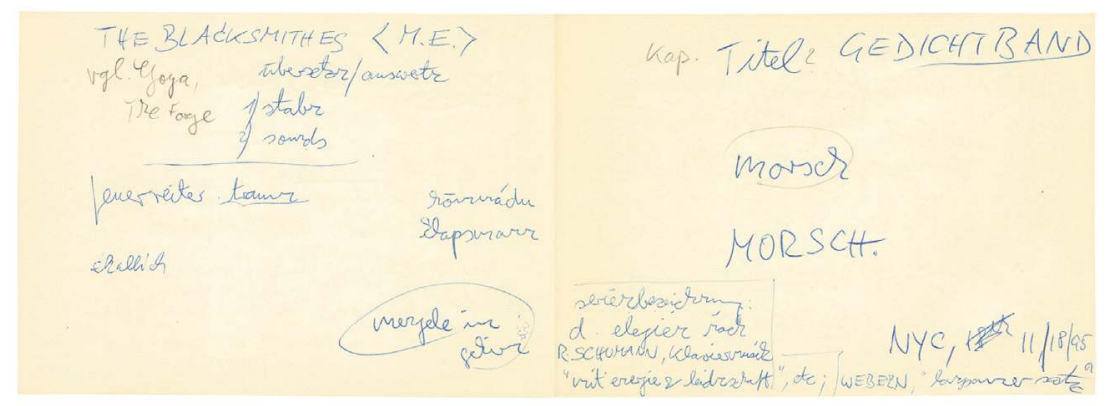

Figure 5: Thomas Kling, AUGN ZEUGN. NYC. Manhattan. Notebook, pp. 24 and 25. Thomas Kling Archiv, Stiftung Insel Hombroich (uncatalogued).

To comment on some of the verses. On the first page of the notebook (see Figure 1) there is a quotation from the German Impressionist poet Max Dauthendey saying that the stage is a brain, which Kling must have found in a book by Albert Soergel. At least, there is a link "SOERGEL" in Kling's notebook, and the nineteenth edition of Soergel's book, Dichter und Dichtung der Zeit, is present in Kling's library. Harshly disrupting the third phrase and destroying all ideas of traditional poetry, the quotation, which looks like a note for a lecture or an essay, is inserted into the poem between brackets and enclosed within quotation marks.

Kling said that he got the idea for the title of his new poetry volume in Manhattan (see Kling 1997 and 2001a, 167). And indeed, on page 25 of the notebook we find the evidence. Kling even noted the exact date: 18 November 1995 (see Figure 5). In the poem, however, the title "morsch" ("rotten") is mentioned in form of the adjective "vermorschtes", emphasizing the result of the process of rotting. There is no equivalent in the English language. The word "SUBWAY" is noted in a context (see Figure 2), which is the subject of stanzas seven and eight. That is why the word "subway" in the eleventh stanza refers rather to the use of the word in the poem itself; but these in-depth relationships would go beyond the scope of this paper. What is most significant for Kling's writing process is the observation that a simple note like " $34^{\text {th }}$ Penn. Station" is not only a tourist's note for a meeting point or a tourist feature as it seems to be at first glance (see Kling 2013, 8). Right from the beginning, it is a sound - it is material which he uses so to speak as a quarry and 
which is noted to be transferred into a poem, someday. In this case, it is the eleventh stanza of the Manhattan poem.

But the relevance of this archival material goes far beyond the Manhattan poems, representing a writing process that Almuth Grésillon describes in her study on the genesis of Francis Ponge's poem "L'Ardoise": 9

Ce qui ne fait pas l'objet de publication, ce qui demeure dans l'atelier de l'écrivain, n'est pas obsolète. Les "matériaux rejetés" de Ponge sont à entendre au contraire comme des éléments mis au jour, sélectionnés dans l'amas des possibles, mis en réserve et prêts à rejaillir un jour ou l'autre. (Grésillon 2007, 167).

[What has not been published yet, what rests in the writer's studio, is not obsolete. On the contrary, Ponge's "rejected materials" are to be understood as elements which are brought to light, chosen within a bunch of possibilities, kept on standby, ready to flare up one day.]

This observation applies equally to Kling. ${ }^{10}$ Just some examples. The interrelation between forging and speaking (see "THE BLACKSMITHES", Figure 5) is subject in the artists' book GELÄNDE. camouflage (TERRAIN. camouflage) (Kling and Langanky 1998; see also Beyer 2014, 125). The word "paläolaryngologie" ("palaeolaryngology") on page 9 of the writing pad (see Figure 4) is used four years later as the title of a poem in Kling's poetry book Fernhandel (Long-distance Trade) (Kling 2000). And finally, a quote from the New York Post of 23 November 1995, which Kling wrote down in his notebook in New York City on page 34 (see Kling 2013, 18), is transferred into the poem "s. caecilia (keyb.)" in a chapter about

9 Quite significantly, the semantic content of the title of Ponge's poem is ambiguous, referring to the mineralogical term "shale" as well as to the text media "slate", a medium which can easily be wiped and rewritten. Here we meet again with Derrida's description of language and writing as "superimposition of a Wunderblock [. . .], palimpsest grid, supersedimented textuality, bottomless stratigraphy" (Derrida 1986, 13).

10 In 1991, talking with Beyer, Kling said that he used to note everything down which drew his attention. The scraps would lie around until he knew what to do with them (see Kling 2012, 44). Consequently, a lot of "rejected materials" for which he had not been able to find any use still remained in Kling's studio. 
Rome in his poetry volume morsch, the one which opens "Manhattan Mundraum".${ }^{11}$ Surprisingly, the insert appears in capital letters and in the original English.

was sagt der obduktionsbe-

richt I'AM GOING TO GET

THEM FOR THIS / SOME-

BODY DID THIS TO MY

DAUGHTER / SOMEBODY

DID VOODOO AND WITCH-

CRAFT TO HER / (Kling 1996, 102)

[what does the autopsy re- I port say [...] ]

The quotation from the New York Post is slightly modified, but the slashes explicitly refer to the line breaks in Kling's original note in his notebook as if it were another poem that he is referring to. By indicating the original line breaks, Kling adds a layer of scholarly practice in a literary genre which is considered to be rather subjective. ${ }^{12} \mathrm{~A}$ similar point is the quote from the poet Dauthendey (see the beginning of the $11^{\text {th }}$ stanza) as well as the use of different fonts in the $7^{\text {th }}$ stanza. "poeta en nueva york" in the first line of the $7^{\text {th }}$ stanza refers to the title of a book of poetry by García Lorca. It is set in italics as is the usual practice in literary studies. A few lines further down, the title reappears, but this time it is set in roman, signalling that it has now become part of Kling's own language in the poem and the poem now talks about him as a poet in New York City. As a visitor to the city, Kling is always fully aware of being a poet at work like García Lorca, Stefan Toller and all the others he is referring to.

11 The collage technique Kling uses here could be considered an homage to Dos Passos, who applied it as early as 1925, prior to Alfred Döblin. See Beyer 2014, 126.

12 Nevertheless, "Manhattan Mundraum" is about existential threats in a large city like New York City; see for example: "di ungezählte angst" (Kling 1996, 9) (the uncounted angst). 


\section{The author and his library}

This reference to other poets in "Manhattan Mundraum" outlines another characteristic feature in Kling's poetry and leads to the second part of my paper touching questions on the relationship between writers and their libraries as well as the large field of research on marginalia (see Jackson 2002). Kling explicitly refers to his library as a source of his writing, and on top of that, as a source of his authorship. ${ }^{13}$ Accordingly, as mentioned before, his way of writing has to be characterized as intertextual more than in regard to any other poet. When Alexander Gumz points out that -

[a] well-grounded knowledge of history, literature, geology, and art history fuses in his poetry by way of harsh treatment with writing techniques from the media age [... .] to form sensual 'language installations', as Kling called them, which remain gripping despite all the rich knowledge injected to them." (Gumz 1995)

- it has to be stated that this "rich knowledge" was gained by taking great pains studying. Kling was a very attentive reader. This becomes obvious at first glance in his library. He not only used to mark the pages in the books with a pencil, on top of that he marked them with yellow post-it-notes on which he noted the catch words.

I focus on only one intertextual reference, that to Paul Celan in the second Manhattan poem, for which we need the personal library to understand it. In the shelf containing the books by and about Celan in Kling's library, volume 2 of the Suhrkamp edition is missing. But Kling had two separate bookshelves next to his writing desk where he kept the main books of reference, and here you find the missing second volume. In "Manhattan Mundraum Zwei", the poem about 9/11, Kling quotes Celan twice, but I only want to mention Kling's reference to the famous lines "wir schaufeln ein Grab in den Lüften da liegt man nicht eng" (Celan 1971, 28 ) ("we are digging a grave in the air there is room for all of us") (Celan 1971, 29) from Celan's poem “Todesfuge" ("Death Fugue") about people dying

13 See "Das Schibboleth hieß immer schon GROSSVATERS BÜCHERSCHRANK" (Kling 1993, 12) ("The shibboleth has always been called GRANDFATHER'S BOOKCASE"). 
in the Nazi concentration camps. Kling writes: "und siedelten in der luft" ("and we settled in the air") ( $8^{\text {th }}$ stanza) "und siedelten so in der luft" ("and we just settled in the air") (9 $9^{\text {th }}$ stanza) about the people dying in the twin towers (Kling 2002, 13). ${ }^{14}$ Research in the library revealed that in Celan's poetry volume, these quotes are not marked, and we learnt that most of the marginal notes do not refer to the content, but to the language used in Celan's poems, "Judenwelsch" or "Gauklergösch". Referring to the reflections on the notion of "variant", the question arises: Could a library be considered to be a stock of variants?

In the process of self-staging, it is in particular Kling's library that is crucial. This can easily be proved by the extensive use of mottos in his poetry books where he used to refer to many other poets, but - remarkably enough - to his own verses as well. There are two mottos preceding "Manhattan Mundraum Zwei". One is by Jacob Balde - Kling was very proud to have a first issue of his medical satires from 1660 in his library (see Kling 2004a). The other one is by himself, a quote from the first stanza of the first Manhattan poem.

. . die / ruinen, nicht hier, die / die zähnung zählung der / stadt!, zu bergn, zu verbergn!

MANHATTAN MUNDRAUM (Kling 2002, 9)

[ . . the / ruins, not here, the / the serration census of the / city!, to hold, to hide!

MANHATTAN MOUTHSPACE]

As mentioned before, in "Manhattan Mundraum Zwei", the poet combines the media reception of 9/11 with his own eye and ear witness of Manhattan in the 1990s. The motto taken from his first Manhattan poem shapes a vision of ruins that - written down in 1995 - actually turned into reality in 2001. Thanks to Marcel Beyer's meticulous analysis of the facsimile edition (Beyer 2014) we know that these "ruins, not here" refer to the destruction in Cologne

14 Michael Hofmann's translation of Kling's second Manhattan poem (see Kling 2004b) does not differentiate between the line "und siedelten in der luft" and its repetition "und siedelten so in der luft". The mottos are not translated by him though they are explicitly part of the poem. In Sondagen, the title of the poem, "Manhattan Mundraum Zwei", can be found on page 9, the mottos on page 10, and the poem begins on page 11 (see Kling 2002). 


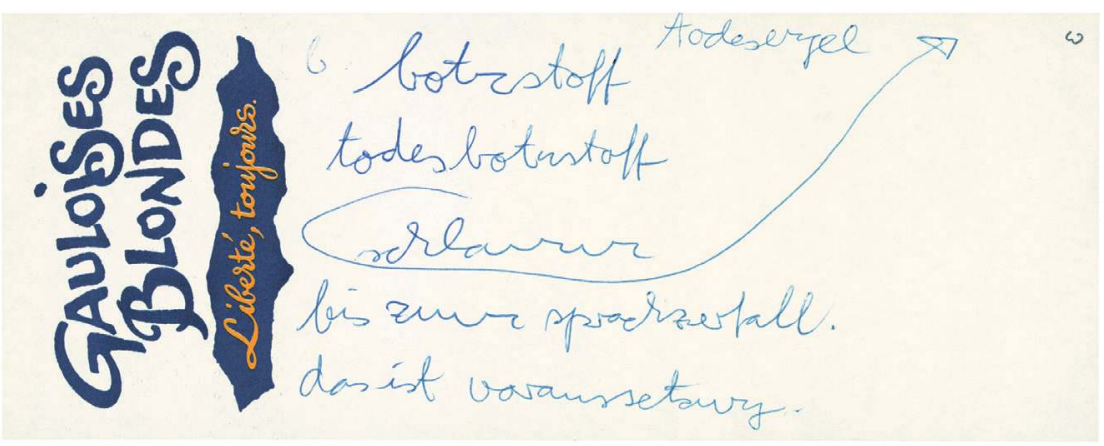

Figure 6: Thomas Kling, Note on a waiter's notepad, not dated. Thomas Kling Archiv, Stiftung Insel Hombroich (HHI.2008.D.Kling.2964)

during the Second World War, or even more precisely to images of the bombing of Cologne in Lars Trier's film Epidemic, which Kling apparently saw during his stay in New York City; at least he kept the ticket for this film in the notebook (see Kling 2013, 9).${ }^{15}$ Against this background, the motto incorporates and interrelates more than sixty years of German and American history; it fuses the author's reception of reality, film and $\mathrm{TV}$, the annihilation of people and cities in the wake of dictatorial and terroristic acts - a reading which is based on stratigraphic soundings, on revealing the archeaeology in the underlying layers and the contexts they came from.

By way of conclusion, I would like to bring various lines of argument together as well as the different aspects of the main topic in the Manhattan poems. It is for this reason that I focus on a unique archival document, the threads of which converge in the overarching motif of the two poems; the documents also bridge the gap with the author's reflections in another publication of that time about the place where he had moved. But above all, this thrilling find in Kling's archive again testifies to the poet's role as an archaeologist of language, which formed for Kling the basis for his language installations; and to the editor's role, who in his endeavour to discover what contexts exist and how they were created can only

15 On the misspelling of "Epedemic" on the ticket from New York City, see Beyer 2014, 130. 
take test drillings into a poetry of "supersedimented textuality" and "bottomless stratigraphy".

The document in question consists of no more than a single sheet taken from a waiter's notepad that bears the imprint "GAULOISES BLONDES. Liberté, toujours" (see Figure 6). Along with inter alia the writing pad containing the notes for the first Manhattan poem, the document was found in a drawer whose contents were labelled with the letter "W" at the top of the slip by the archivist. The few notes that Kling wrote on the waiter's notepad, which he used in landscape format, are carefully laid down one below the other, reading: "botnstoff" ("messnger"), "todesbotnstoff" ("messnger of death"), "schlamm" ("mud"), "bis zum sprachzerfall" ("until the decay of language") and "das ist voraussetzung" ("this is a prerequisite"). Another word in smaller letters on the top of the sheet, obviously added subsequently, reads "todesengel" ("angel of death"), and the word "schlamm" ("mud") has been moved next to it with an elegantly curved line ending in an arrow. Contrary to the promises of the advertisement, Kling's notes are about ruin and death, the leitmotifs of both Manhattan poems.

Certainly, the term "Botenstoff" ("messenger" or "semiochemical") plays an important role in Kling's poetics. Originally used in chemical ecology as a generic term for all chemical substances that are able to transfer a signal (see Greek semeon, "signal") into an organism or between individuals of the same species - and even of different species - for the purpose of communication, it works as a metaphor for the function of language and particularly for poetry in Kling's poetics. In 2001, he titled an anthology of his essays Botenstoffe (Messengers) referring to a paper from the 1990s. ${ }^{16}$ Kling also used the term in his collaboration with Ute Langanky, GELÄNDE. camouflage, which was published only in 1998, but originated from 1995/96, when they had moved to the Raketenstation Hombroich. Langanky's photos were taken against the low sun giving an impression of the ambiguous, strained atmosphere of this former missile base which was to become a

16 As seen before, Kling used to write in lowercase letters and to imitate oral speech in a kind of phonetic transcription, e.g. by omitting unstressed vocals. Like "geschmo- I lzner text" (correctly,"geschmolzener Text"), the word "Botenstoff" reads "botnstoff" in his poem and notes, whereas the title of his essay volume reads "Botenstoffe" according to the Duden spelling rules. 
place for artists to live and to work. A line in Kling's poem from this book reads "botnstoff licht" (Kling and Langanky 1998, n.p.) ("messnger light"), which alludes to the function of light, as the condition by which human eye as well as the camera can register things, and also to the danger of fire and the explosion of missiles, which refers in turn to the notes on the waiter's notepad: "botnstoff", "todesbotnstoff", "sprachzerfall". The latter, however, was modified and reads "blicknamenzerfall" in the final stanza of the first Manhattan poem, a neologism composed of glance, name and decay, which illustrates the volatility of the (language) perception in a cosmopolitan city. Just a few notes thus generate the semantic field of light and language as messengers giving access to seeing and naming on the one hand, but on the other hand requiring the decay of language to create a new writing process, a new vibration of language and thereby a new poetry: "das ist voraussetzung" this is the prerequisite.

In our exhibition on Kling's writing process, an entire display case was devoted to this artefact from the archive. Is it necessary to add that, of course, the discovery of this slip of paper was not a matter of chance? On the contrary, this "discovery" may clarify the correlation between the writing process and the archive. It is evidence of a poet's way of working, a poet who deliberately collected and stored documents with regard to his archive, be it a waiter's notepad or a cinema ticket. ${ }^{17}$ To all intents and purposes, this implies that the place where Kling had been writing did not become an archive posthumously. It had always been one.

\section{Bibliography}

Beyer, Marcel. 2012. “Thomas Kling: Herz". In Norbert Wehr and Ute Langanky (eds.), Thomas Kling: Das brennende Archiv. Berlin: Suhrkamp, pp. 175-87.

—_. 2014. "Thomas Kling. New York State of Mind". In Sprache im technischen Zeitalter 209, pp. 123-35.

Celan, Paul. 1971. Speech-Grille and Selected Poems. Trans. Joachim Neugroschl. New York: E. P. Dutton.

17 Even his friends did not know what a wealth of material Kling had collected and stored, especially since Kling had always been rather critical of literary archives. See Beyer 2012, 177. 
Dedner, Burghard. 2012. "Intertextual Layers in Translations. Methods of research and Editorial Presentation". In Wout Dillen, Caroline Macé and Dirk Van Hulle (eds.), Texts beyond Borders: Multilingualism and Textual Scholarship. Special issue of Variants 9, pp. 115-31.

Derrida, Jacques. 1986. "Point de folie: Maintenant l'architecture" / "Point de folie: Maintenant l'architecture - Essay accompanying the portfolio". Trans. Kate Linker. In Bernard Tschumi. La case vide: La Villette 1985. London: Architectural Association, pp. 4-19.

Grésillon, Almuth. 2007. "Francis Ponge, L'Ardoise dans tous ses états'". In La Bibliothèque littéraire Jacques Doucet: archive de la modernité. Paris: Presses Sorbonne Nouvelle. Les Editions des Cendres, pp. 149-74.

Gumz, Alexander. 2005. "Thomas Kling". In Poetry International Rotterdam, 1 July 2005. <http://www.poetryinternationalweb. net/pi/site/poet/item/2219/19/thomas-kling>. [Accessed 18 April 2014].

Harris, Edward. 1997. Principles of Archaeological Stratigraphy. (3 ${ }^{\text {rd }}$ printing. First published 1979). London et al.: Academic Press.

Hay, Louis. 1984. "Die dritte Dimension der Literatur: Notizen zu einer 'critique génétique'"'. In Poetica: Zeitschrift für Sprach- und Literaturwissenschaft, 16, pp. 307-323.

Jackson, Heather J. 2002. Marginalia: Readers Writing in Books. New Haven: Yale University Press.

Kling, Thomas. 1977. Der Zustand vor dem Untergang. Düsseldorf: Kunstverlag Schell und Scherenberg.

—_. 1993. "Sprachinstallation Lyon". In Frieder von Ammon, Peer Trilcke and Alena Scharfschwert (eds.). Das Gellen der Tinte: Zum Werk Thomas Klings. Göttingen: V\&R unipress, pp. 11-12.

—_. 1996. morsch. Gedichte. Frankfurt a. M.: Suhrkamp.

—_. 1997. Dankrede. Peter-Huchel-Preis, $3^{\text {rd }}$ April 1997. <http:// peter-huchel-preis.de/preistraeger/1997-thomas-kling/>. [Accessed 18 April 2014]

—_. 2000. Fernhandel. Gedichte. Köln: DuMont.

—_. 2001a. Botenstoffe. Köln: DuMont.

—_. 2001b. Sprachspeicher. 200 Gedichte auf deutsch vom achten bis zum zwanzigsten Jahrhundert. Köln: DuMont.

—_. 2002. Sondagen. Gedichte. Köln: DuMont. 
—_. 2004a. E-Mail to the Swedish translator Lars-Inge Nilsson. 25 January. Thomas Kling Archiv, Stiftung Insel Hombroich. HHI.2008.D.KLING.507.

_ - 2004b. Translation of Thomas Kling, "Manhattan Mouthspace Two". Trans. Michael Hofmann. In Thomas Wohlfahrt and Tobias Lehmkuhl (eds.). Mouth to Mouth: Contemporary German Poetry in Translation. Newcastle, Australia: Giramondo Publishing Company. <http://www.poetryinternationalweb.net/pi/ site/poem/item/2369/auto/MANHATTAN-MOUTHSPACE-TWO> [Accessed 18 April 2014]

——. 2005. Auswertung der Flugdaten. Köln: DuMont.

- 2006. "Sprachinstallation 1" / "Sprachinstallation 2" (1997). In Itinerar. Frankfurt a.M.: Suhrkamp, pp. 9-13 and 15-26.

—_. 2013 Zur Leitcodierung: Manhattan Schreibszene. Eds. Kerstin Stüssel and Gabriele Wix. Göttingen: Wallstein.

__ and Marcel Beyer. 1991. “Das Eingemachte: Marcel Beyer und Thomas Kling beim Smalltalk — Auszüge". In Thomas Kling: Das brennende Archiv. Eds. Norbert Wehr and Ute Langanky 2012. Berlin: Suhrkamp, pp. 43-49.

—_ and Ute Langanky. 1998. GELÄNDE. camouflage. Münster: Kleinheinrich.

Scharfschwert, Alina. 2012. "Das eingepflegte Archiv". In Frieder von Ammon, Peer Trilcke and Alena Scharfschwert (eds.), Das Gellen der Tinte: Zum Werk Thomas Klings. Göttingen: V\&R unipress, pp. 383-89.

Schwitters, Kurt. 1998. Das literarische Werk. 5 vols. Ed. Friedhelm Lach. Köln: DuMont.

—_. 2014. Die Sammelkladden 1919-1923. Vol. 3. of Alle Texte. Eds. Ursula Kocher and Isabel Schulz. Berlin: de Gruyter

Trakl, Georg. 1969. Dichtungen und Briefe: Historisch-kritische Ausgabe. Eds. Walther Killy and Hans Szklenar. Otto Müller: Salzburg.

__. 1995-2014. Sämtliche Werke und Briefwechsel: Historisch-kritische Ausgabe mit Faksimiles der Handschriften Trakls. Eds. Eberhard Sauermann and Hermann Zwerschina. Basel: Stroemfeld.

Trilcke, Peer. 2012. "Klings Zeilen: Philologische Betrachtungen." In Frieder von Ammon, Peer Trilcke and Alena Scharfschwert (eds.), Das Gellen der Tinte: Zum Werk Thomas Klings. Göttingen: V\&R unipress, pp. 293-325. 
Tschumi, Bernard. 1994. The Manhattan Transcripts. New ed. London: Academy Edition.

Wix, Gabriele. 2015. "'Am Abend, wenn', Georg Trakl: Vom Nutzen konkurrierender Editionen: Salzburger und Innsbrucker TraklAusgabe“. In Thomas Bein (ed.), Vom Nutzen der Editionen. Beihefte zu editio 39. Berlin: De Gruyter, pp. 397-411. 